\title{
Effect of duration of time and dosage on fermentation of cacao pod by using Indigenous Microorganism YL (MOIYL)
}

\author{
E Wulandari, T H Wahyuni, Hasnudi, N Ginting, M Tafsin \\ Animal Production Program Study, Faculty of Agriculture, University of North \\ Sumatera, Medan 20155, Indonesia \\ E-mail: oppowulandari4@gmail.com
}

\begin{abstract}
The main problem with cocoa pod is the high crude fiber content and low crude protein. A treatment needed to change the nutritional content, one of which is fermentation. In this study, fermentation used Indigenous microorganisms which were YL (MOIYL). This research lasted for 3 months which was carried out from July to September 2018 at the Laboratory of Animal Production and the Laboratory of Animal Nutrition Sciences at the Faculty of Agriculture, University of North Sumatra. The research design used was Factorial 4 x 4 Completely Randomized Design (CRD), with 3 replications where factor 1 was the various levels of inoculum of Indigenous YL (MOIYL) and factor 2 was the length of fermentation (incubation) with measured parameters of crude protein, crude fiber, crude fat, and ash content using proximate analysis.

The results showed that cocoa pod fermentation using Indigenous YL (MOIYL) microorganisms could improve the quality of nutrient content including the highest water content with a dose of $3 \%$ with a 7 day fermentation of $11.75 \%$ and the lowest without Moiyl with 21 days fermentation time of $10.02 \%$. highest crude protein with $5 \%$ dose with 7 days fermentation of $11.89 \%$ and the lowest without Moiyl with 28 days fermentation of $7.18 \%$, highest crude fat at $5 \%$ with 7 days fermentation at $1.33 \%$ and the lowest without Moiyl with 28 days fermentation time is $1.22 \%$, while the highest crude fiber is $5 \%$ with 7 days fermentation of $21.3 \%$ and the lowest is $5 \%$ with 28 days fermentation of $23.93 \%$, the highest dry matter is $3 \%$ with 7 days fermentation time equal to $88.24 \%$ and the lowest without Moiyl with 7 days long $89.95 \%$, highest ash content with d osis $1 \%$ with a 7 day fermentation time of $9.52 \%$ and the lowest ash content without Moiyl with a 7 day fermentation time of $11.17 \%$. The results of this study concluded that cocoa pod fermentation using 5\% Indigenous YL (MOIYL) microorganisms and 7 days fermentation time could increase water content, crude protein, and crude fat, while crude fiber, dry matter, and ash content decreased.
\end{abstract}

\section{Introduction}

Availability of animal feed is a major problem in the development of livestock. When viewed in terms of production costs in a livestock business, food costs are the highest costs compared to other production costs. This food cost can reach more than $75 \%$ of the total production cost. Therefore, it is important to look for alternative ingredients that can be used as substitute feed ingredients with the same nutritional content as other staples. 
One alternative that can be taken is by adding knowledge about natural resources that can be used as alternative animal feed for example, waste from plantation crops such as cocoa / chocolate can be produced on a large enough scale and allows it to be used as an alternative ingredient for animal feed.

The cocoa pod contains $8.5 \%$ crude protein and $27 \%$ crude fiber, so it is more used as ruminant feed than monogastric animals. Furthermore, it was explained that cocoa pods cannot be given to monogastric animals because the lignin content is quite high, reaching $38.70 \%$ and the presence of theobromine and there is an antinutrient of tannins which limits the use of this cocoa pod (Wong et al., 1987).

The provision of cocoa pods can directly reduce livestock body weight because of the low protein content and high levels of lignin and cellulose. Therefore, before being given to livestock, it should be fermented first to reduce the levels of lignin which is difficult to digest by livestock and to increase the nutritional value of good for livestock with a concentration limit in its use because it contains the theobromine anti-nutrient compounds.

Wina (2005) said that low-quality feed with high lignin content would cause poor rumen conditions and functions, so technology was needed to improve it. Fermentation is one of the technologies to improve feed quality from waste, because the involvement of microorganisms in degrading crude fiber, reducing levels of lignin and anti-nutrient compounds, so that the digestibility of feed from waste can increase.

One of the fermentation that can be done is by using Moiyl and allowing it to be closed in a certain time. Moiyl is a local microorganism originating from oil palm plantation waste which has the potential to degrade fiber (Yunilas, 2016).

\section{Materials and Methods}

\subsection{Time and place of research}

This study lasted for 3 months which was conducted from July to September 2018 at the Animal Production Laboratory and the Laboratory of Animal Nutrition Sciences at the Faculty of Agriculture, University of North Sumatra.

\subsection{Sampling technique}

The research design used was Factorial 4x4 RAL, with 3 replications.

Factor I Various levels of MOIYL Probiotic inoculum

$\mathrm{AO}=$ No Moiyl

$\mathrm{A} 1=1 \%$ MOIYL Probiotics

$\mathrm{A} 2=3 \%$ MOIYL Probiotics

$\mathrm{A} 3=5 \%$ MOIYL Probiotics

Factor II = Duration of Fermentation (Incubation)

$\mathrm{B} 1=7$ days

$\mathrm{B} 2=14$ days

$\mathrm{B} 3=21$ days

$\mathrm{B} 4=28$ days

\subsection{Measured parameters}

The parameters measured in this study were the nutritional content of fermented cocoa pods using MOIYL.

Based on the proximate analysis as follows: crude protein, crude fiber, crude fat and ash content 


\subsection{Processing Method and Analysis data}

\subsubsection{Preparation of Cocoa Pod Waste}

Cacao pod waste is chopped first, after which the chopped pod is aerated until the water content is reduced.

Increase Moiyl

Provide 1 liter of bioactivity, $1 \mathrm{~kg}$ of brown sugar, 1 liter of coconut water, 2-3 pieces of pineapple fruit (1 liter of pineapple water). First brown sugar in slices and then cook add enough water, wait for it to cool. After squeezing the pineapple, take the water, then mix all the ingredients that have been supplied into the dregen. Then save for 7 days.

Mixing of Materials and packaging

The cacao pod that has been chopped and aerated is carried with the sun mixed with rice bran 3\% from 1000 grams of cacao pods (30 grams) stir until evenly distributed, then molasses $3 \%$ of 1000 grams of cocoa pods (30 grams) dissolved in enough water, then mix molasses into a cocoa pod that has been mixed with bran evenly, then spray MOIYL with various levels of use, namely $1 \%, 3 \%, 5 \%$, with (fermentation) that is 7 days, 14 days, 21 days and 28 days, then put into plastic then compacted so that anaerobic state is created, then tied and coated with the second plastic, then the plastic is put into the third plastic again, then tied again and stored according to the time of treatment.

4. Sample Testing

After the fermentation process is completed according to each treatment $(7,1421$, and 28 days with a dose of $1 \%, 3 \%, 5 \%)$, the plastic is opened then each plastic bag is taken and put into the oven at 60 degrees Celsius for 24 hours to stop fermentation Then the sample is tested for fermented waste in the following manner: the sample is dried in the oven for 8 hours at a temperature of 105 degrees Celsius or until the weight is constant, then weighed. Then a proximate analysis was carried out at the Livestock Production Laboratory and the Animal Nutrition Sciences Laboratory of the Faculty of Agriculture, University of North Sumatra.

\subsubsection{Data Analysis}

The data obtained from the test results were analyzed using analysis of variance (ANNOVA), if there were significant influences between treatments, then proceed using Duncan's Multiple Range Test (DMRT).

\section{Results and Discussion}

\subsection{Crude Protein}

Diversity analysis showed that there was an interaction between inoculum dose and fermentation time which had a very significant effect $(\mathrm{P}<0.05)$ on crude protein in cocoa pod fermentation (Appendix 1). Based on the Duncan test results showed an interaction between the two factors causing an increase in crude protein content, there was the highest increase in crude protein in A3B1 from $7.31 \%$ to $11.89 \%$ or $38.60 \%$ and the lowest in theA0B4 average from $7.31 \%$ to $7.18 \%$ or $1.67 \%$.

Increasing protein levels in this study are in line with the amount of inoculum given, the number of doses given is greater, the crude protein content is higher due to a decrease in fiber content and antinutrient compounds present in the cocoa pod.

This is presumably because during fermentation, indigenous microorganisms YL undergo division resulting in more bacteria where bacteria can produce proteins called single cell proteins and have 
a body structure mostly from protein so that the crude protein present in the cocoa pod increases due to the number of cells bacteria that grow during fermentation. This is in accordance with Suprihatin's statement (2010), bacteria are prokaryotic cells that grow by dividing symmetrically into two cells, while growth is influenced by several factors the time needed to divide.

\begin{tabular}{|c|c|c|c|c|c|c|}
\hline \multirow{2}{*}{ Dosis Moiyl } & \multicolumn{5}{|c|}{ Lama Fermentasi } & \multirow{2}{*}{ Rataan } \\
\hline & B1 & B2 & B3 & B4 & & \\
\hline A0 & $1.45^{\mathrm{bA}}$ & $1.37^{\mathrm{bA}}$ & $1.3^{\mathrm{bA}}$ & $1.22^{\mathrm{aA}}$ & 1.34 & \\
\hline A1 & $\begin{array}{l}1.4 \mathrm{~J} \\
2.77^{\mathrm{bB}}\end{array}$ & $2.46^{\mathrm{bB}}$ & $2.47^{\mathrm{bB}}$ & $2.18^{\mathrm{aB}}$ & 2.47 & \\
\hline $\mathrm{A} 2$ & $2.87^{\mathrm{bB}}$ & $2.57^{\mathrm{bB}}$ & $2.54^{\mathrm{bB}}$ & $2.34^{\mathrm{aB}}$ & 2.58 & \\
\hline A3 & $2.97^{\mathrm{bB}}$ & $2.64^{\mathrm{bB}}$ & $2.64^{\mathrm{bB}}$ & $2.54^{\mathrm{aB}}$ & 2.69 & \\
\hline Rata-rata & 2.51 & 2.26 & 2.23 & 2.07 & & \\
\hline
\end{tabular}

3.2 Rough Fiber

Table 2. Rough fiber cocoa pod coarse a after fermentation

\begin{tabular}{|c|c|c|c|c|c|}
\hline \multirow{2}{*}{ Dosis Moiyl } & \multicolumn{4}{|c|}{ Lama Fermentasi } & \multirow{2}{*}{ Rataan } \\
\hline & B1 & B2 & B3 & B4 & \\
\hline A0 & $33.42^{\mathrm{bB}}$ & $33.34^{\mathrm{bB}}$ & $33.28^{\mathrm{bB}}$ & $33.18^{\mathrm{aB}}$ & 33.30 \\
\hline A1 & $21.57^{\mathrm{aB}}$ & $21.77^{\mathrm{bA}}$ & $22.74^{\mathrm{bB}}$ & $23.54^{\mathrm{bA}}$ & 22.40 \\
\hline A2 & $21.44^{\mathrm{aB}}$ & $21.82^{\mathrm{bB}}$ & $22.64^{\mathrm{bB}}$ & $23.75^{\mathrm{bB}}$ & 22.42 \\
\hline A3 & $21.3^{\mathrm{Aa}}$ & $21.88^{\mathrm{bB}}$ & $22.55^{\mathrm{bA}}$ & $23.93^{\mathrm{bB}}$ & 22.41 \\
\hline Rata-rata & 24.43 & 24.70 & 25.30 & 26.1 & \\
\hline
\end{tabular}

Diversity analysis showed that there was an interaction between the inoculum dose and fermentation time which had a very significant effect $(\mathrm{P}<0.01)$, on cocoa pod crude fermentation fibers (Appendix 2). Based on the Duncan test results showed an interaction between the two factors causing a decrease in crude fiber content, there was a decrease in the crude fiber content which was the highest in A3B1 from $33.31 \%$ to $21.3 \%$ or $36.05 \%$ and the lowest was on the A3B4 average of $33.31 \%$ to 23.93 or $28.15 \%$.

The results of this study indicate that the longer the fermentation time and the higher the dose given, the value of crude fiber content decreases. This is presumably because the cellulase enzymes that are produced are increasing with increasing doses of inoculum and fermentation days so that more microbial opportunities to degrade cellulose and ligninselulose at a certain time limit.

This is in accordance with Yunilas et al., (2013) statement which states that the decrease in crude fiber occurs because microbial activity during fermentation can produce enzymes that degrade crude fiber substrates. In addition, the decrease in crude fiber content is thought to be due to the addition of certain ingredients such as molasses and rice bran.

\subsection{Crude Fat}

Table 3. Crude fat cocoa pod coarse a after fermentation 


\begin{tabular}{lccccc}
\hline \multirow{2}{*}{ Dosis Moiyl } & \multicolumn{5}{l}{ Lama Fermentasi } \\
\cline { 2 - 5 } & $\mathrm{B} 1$ & $\mathrm{~B} 2$ & $\mathrm{~B} 3$ & $\mathrm{~B} 4$ & Rataan \\
\hline $\mathrm{A} 0$ & $11.17^{\mathrm{Bb}}$ & $11.09^{\mathrm{Bb}}$ & $10.99^{\mathrm{Bb}}$ & $10.93^{\mathrm{Ba}}$ & 11.04 \\
$\mathrm{~A} 1$ & $9.52^{\mathrm{Aa}}$ & $9.75^{\mathrm{Ab}}$ & $10.44^{\mathrm{Ab}}$ & $10.76^{\mathrm{Ab}}$ & 10.11 \\
$\mathrm{~A} 2$ & $9.56^{\mathrm{Ba}}$ & $9.83^{\mathrm{Bb}}$ & $10.52^{\mathrm{Bb}}$ & $10.84^{\mathrm{Bb}}$ & 10.18 \\
A3 & $9.65^{\mathrm{Ba}}$ & $9.9^{\mathrm{Bb}}$ & $10.62^{\mathrm{Bb}}$ & $10.85^{\mathrm{Bb}}$ & 10.25 \\
\hline Rata-rata & 9.97 & 10.14 & 10.64 & 10.84 & \\
\hline
\end{tabular}

Diversity analysis showed an interaction between the dose of inoculum and the duration of fermentation had a very significant effect $(\mathrm{P}<0.01)$, on crude pods of cocoa pod fermentation (Appendix 3). Based on the Duncan test results showed an interaction between the two factors causing an increase in crude fat content, there was an increase in the highest crude fat content in A3B1 from $1.34 \%$ to $2.97 \%$ or $54.88 \%$ and the lowest was in the A0B4 average from $1.34 \%$ to $1.2 \%$ or equal to $11.66 \%$.

The results of this study indicate that the crude fat content is high because of the drying process with the sun, in accordance with the results of Erlinawati (2012) who said that high fat content in fat can occur as a result of giving high heat to fat and breaking bonds double on fat. Fat is a compound formed as a result of an esterification reaction between glycerol and fatty acids.

The highest crude fat content is found in sun drying. This is due to the evaporation of water from the material in large quantities so that the water content decreases and causes an increase in crude fat. In accordance with the opinion of Rahayu (1992) that fat content is inversely proportional to water content. High fat content usually has a lower water content. This is supported by Buckle (1987) that during the drying process, water evaporates from the surface with speed depending on the drying temperature, but then after critical moisture content is reached, the water that will evaporate must diffuse from the material. This is what causes fat levels to increase.

\subsection{Ash content}

Diversity analysis showed an interaction between the dose of inoculum and the duration o fermentation significantly affected $(\mathrm{P}<0.01)$, on the levels of cocoa pod fermentation ask (Appendix 4). Based on the Duncan test results showed an interaction between the two factors causing a decrease in ash content, there was a decrease in the highest ash content in A1B1 from $11.04 \%$ to $9.52 \%$ or $15.96 \%$ and the lowest was at $\mathrm{A} 0 \mathrm{~B} 1$ average from $11.04 \%$ to $11.17 \%$ or equal to $1.16 \%$.

The decrease in ash content due to microorganisms has not overhauled the inorganic material found in the cocoa pods, this is due to the dissolution of silica found in the skin of the cocoa fruit, while silica is part of the ash. Lignin is a food that is difficult to digest with cellulose to form a component called lignosellulose which has a very low digestion coefficient Tillman et., Al. (1989). The skin of fermented cocoa can cause some silica and lignin to dissolve in alkaline solutions and this will reduce the ash content.

The decrease in crude fiber is closely related to the decrease in ash content in a feed ingredient Wibowo (2010), indicating that the levels of crude fiber and ash content have a positive relationship, high crude fiber will have a positive effect on the amount of ash content of a feed material. This decrease in ash content is highly expected, because the higher the ash content decreases, the higher the content of organic matter. 


\section{Conclusion}

Cocoa pod fermentation using 5\% Indigenous YL (MOIYL) microorganisms and 7 days fermentation time can increase crude protein, and crude fat, while crude fiber, and ash content decrease.

\section{References:}

[1] Erlinawati.1986. Kemungkinan Penggunaan Kulit Biji Coklat (Theobroma cacao L.) untuk Bahan Makanan Ternak Domba. Karya Ilmiah. Fakultas Peternakan. Institut Pertanian Bogor. Bogor.

[2] Rahayu, W. P,.S. Ma'oen, Suliantari dan S. Fardiaz. 1992. Teknologi Fermentasi Produk Perikanan. Pusat Antar Universitas Pangan dan Gizi.Institut Pertanian Bogor.Bogor.

[3] Suprihatin. 2010. Teknologi Fermentasi. UNESA Press. Surabaya.

[4] Tillman, A. D., 1982. Ilmu Makanan Ternak Dasar. Gadjah Mada University Press.Yogyakarta.

[5] Wina, E. 2005. Teknologi Pemanfaatan Mikroorganisme Dalam Pakan Untuk Meningkatkan Produktivitas Ternak Ruminansia di Indonesia. Sebuah Review. Wartazoa 15(4): 173-186.

[6] Wong, H. K., A. H. Osman and M, S. Idris 1987. Utilization of cocoa by product as ruminant feed. In: Dixon R. M (Ed) Ruminant Feeding System Utlizing Fibrous Agricultural Residues. 1986. School of Agriculture and Forestry. University of Me bourne.Parkville. Victoria.

[7] Yunilas, Lili Warly, Yetti Marlida., and Irsan Riyanto. 2013. Potency of Indigenous Bacteria from Oil Palm Waste in Degrades Lignocellulosa as A Sources of Inoculum Fermented to High Fibre Feed. Pakistan Journal of Nutrition. 12(9): 851-853. 